Article

\title{
Assessment of Physical-Chemical Drinking Water Quality in the Logone Valley (Chad-Cameroon)
}

\section{Sabrina Sorlini $^{1, *}$, Daniela Palazzini ${ }^{1}$, Joseph M. Sieliechi ${ }^{2}$, Martin B. Ngassoum ${ }^{2}$}

1 Faculty of Engineering, University of Brescia, DICATAM, via Branze 43, 25123 Brescia, Italy; E-Mail: danypa@tiscali.it

2 Department of Applied Chemistry, University of Ngaoundéré, ENSAI, P.O. Box. 455 Ngaoundéré, Cameroon; E-Mails: jsieliechi@yahoo.fr (J.M.S.); ngassoum@yahoo.fr (M.B.N.)

* Author to whom correspondence should be addressed; E-Mail: sabrina.sorlini@ing.unibs.it; Tel.: +39-0303711299; Fax: +39-0303711312.

Received: 10 May 2013; in revised form: 28 June 2013 / Accepted: 4 July 2013 /

Published: 15 July 2013

\begin{abstract}
Unsafe drinking water is one of the main concerns in developing countries. In order to deal with this problem, a cooperation project was set up by the ACRA Foundation in the Logone valley (Chad-Cameroon). Water supplies were sampled throughout the villages of this area mostly from boreholes, open wells, rivers and lakes as well as some piped waters. The samples were analysed for their physical-chemical and microbiological quality in order to identify the contamination problems and suggest appropriate solutions. Results of the assessment confirmed that in the studied area there are several parameters of health and aesthetic concern. Elevated lead levels were detected both in aquifers and in surface waters, confirming that further investigations of the occurrence of lead contamination in the Logone valley are warranted. In addition, many groundwater sources are negatively impacted by parameters of aesthetic concern, such as turbidity, iron and manganese. Even though they do not affect human health, elevated levels of these parameters cause consumers to abandon improved water supplies, often in favour of surface water sources that are microbiologically contaminated. The use of alternative sources, improvement of water supply structures and water treatment are possible solutions to improve the quality of drinking water in the Logone valley.
\end{abstract}

Keywords: Chad-Cameroon; drinking water sources; physical-chemical quality 


\section{Introduction}

Inadequate water supply is still one of the major challenges in developing countries. The Joint Monitoring Programme (JMP) for Water Supply and Sanitation, implemented by the World Health Organisation (WHO) and UNICEF, reports that 783 million people in the world $(11 \%$ of the total population) have no access to safe water, $84 \%$ of whom live in rural areas [1]. About 187 million people use surface water for drinking purposes; 94\% of them are rural inhabitants and they are concentrated in sub-Saharan Africa [1]. At a national level, in Chad and Cameroon, it is estimated that $49 \%$ and $23 \%$ of the population has no access to improved water sources respectively [1]. Disparities between urban and rural areas are evident mainly in Cameroon, where $48 \%$ and $5 \%$ of rural and urban inhabitants respectively use surface waters or other unimproved sources [1]. In Chad, 56\% of rural inhabitants and $30 \%$ of urban inhabitants have no access to safe water [1].

Regarding the quality of drinking water, microbiological contamination is a primary concern of developing countries. In addition, inorganic contaminants, concerning both health and aesthetic aspects, can be present in the waters. Fluoride and arsenic are a great health problem worldwide. The public health burden of these two chemicals far exceeds that of other chemical contaminants in drinking-water, but globally it is masked by the public health impact of microbial contamination [2]. Since the discovery of arsenic in Bangladesh, many countries have done at least some chemical testing, but in many cases there is little or no information about arsenic and fluoride in drinking-water [2]. Also other physical-chemical parameters can deteriorate water quality. Heavy metals, like lead, chromium (VI), cadmium and mercury are dangerous for human health, since they are toxic and can be carcinogenic. In spite of this, few studies have been conducted to assess their concentrations in drinking water in developing countries. A monitoring programme executed in Cambodia [3] reported elevated levels of lead, selenium, molybdenum and chromium only in a limited number of cases. Mercury was marginally detected in some surface and ground waters in Ghana [4]. Another study conducted in Ghana [5] also found concentrations of lead, uranium and boron above the World Health Organisation (WHO) Guide Values (GVs) in restricted areas. Low metallic content was observed for most water samples analysed in Bangladesh [6]. Adekunle et al. [7] showed that in some rural settlements in Nigeria most of the water samples from hand-dug wells, in the residential areas near the municipal dumps, contained $\mathrm{Pb}$ and $\mathrm{Cd}$ above the WHO limits for drinking water. Also iron and manganese can be present in surface and ground waters at levels ranging from 0.5 to $50 \mathrm{mg} / \mathrm{L}$ and from $1 \mu \mathrm{g} / \mathrm{L}$ to $10 \mathrm{mg} / \mathrm{L}$, respectively [8]. Concentrations exceeding WHO GVs, respectively $0.3 \mathrm{mg}$ Fe/L and $0.4 \mathrm{mg} \mathrm{Mn} / \mathrm{L}$, were found in Cambodia [3], Zimbabwe [9], Ghana [4,5], Cameroon [10], Pakistan [11] and Bangladesh [6]. Sharaky et al. [12] observed in the groundwater in the Nile delta area concentrations of trace elements lower than the standard limits, except for iron, manganese and nickel. They suggested that iron was most probably produced from iron oxides that occurred in the Pleistocene sediments and that the other trace elements $(\mathrm{Zn}, \mathrm{Pb}, \mathrm{Cd}, \mathrm{Cr}$ and $\mathrm{Cu})$ were most probably attributed to secondary minerals in the aquifer rocks. Cobbina et al. [13] showed that in 129 boreholes in the Sahelian region of northern Ghana total iron, manganese, lead, arsenic and fluoride concentrations were above the WHO limits. They suggested that the presence of iron in these boreholes could be due to its percolation from granitic and metamorphosed rocks into groundwater. Turbidity is a typical problem of surface waters and shallow open wells, as observed in the studies done in Cameroon [14], 
Malawi [15], Ghana [4,5], Pakistan [11] and Bangladesh [6], but it can also affect boreholes as reported in Zimbabwe [9] and Ghana [5]. Ketchemen's work [16] on the underground waters in the far north of Cameroon showed that nitrate levels were above the standards and this high content was linked to human activities.

In 2009, ACRA (Association for Rural Cooperation in Africa and Latin America), in collaboration with the Universities of Brescia (Italy) and Ngaoundéré (Cameroon) and other partners, started the cooperation project "Applied research for the exploitation and processing of natural resources within a pathway of poverty reduction in Chad and Cameroon" in the Logone river valley on the border between Chad and Cameroon. One of the aims of the project was to improve the quality of drinking water. The research described in this paper was carried out to assess the physical-chemical quality of drinking waters, to identify the villages using unsafe sources and to suggest possible solutions to reduce the problems of contamination.

\section{Materials and Methods}

\subsection{Description of the Sampling Site}

The study area is a valley crossed by the Logone river and located on the border between Chad and Cameroun (Figure 1a). The zone is part of the Mayo-Danay Department in Cameroon and the Mayo-Kebby Region in Chad. It is mainly a rural area with difficult access to safe water. The Logone-Chari (Chad) piezometric map reveals piezometric anomalies that have been interpreted as depressed aquifers. The depth of the water table is $60 \mathrm{~m}$ in the Tagawa-Am Talia axis, $40 \mathrm{~m}$ between Louba-Louba and Andirni and $30 \mathrm{~m}$ around Yagoua [17]. An initial survey was carried out in order to investigate the practices of the local population regarding water management and to collect information on socio-economic, sanitary and environmental aspects. Thirty seven villages in the valley (18 in Chad and 19 in Cameroon) were visited and 278 questionnaires were submitted to local families. The total number of people targeted in this survey was about 3340 (corresponding to about 12 people/family). After this, 14 representative villages (seven in Chad and seven in Cameroon) were selected to continue the monitoring program. The villages were chosen by considering two criteria: the water source most used by the families investigated in the survey (Table 1) and the location of the village (Figure 1b). Both in Cameroon and in Chad, people were using different types of sources in addition to the primary one indicated in Table 1. This means that people living in the same village can use both improved and unimproved sources, which may have different health effects. In particular, from the survey $94 \%$ and the $78 \%$ of the population interviewed respectively in Chad and Cameroon were using unimproved sources. This difference between the two countries regarding access to safe water is in agreement with the national data reported in the Introduction. When the typology of the water sources and the location of the villages were similar, the monitoring programme was carried out in the villages with a higher percentage of unsafe domestic buckets used to store water, a higher percentage of people affected by a diarrhoeal disease and a greater willingness to pay for an improvement in the water sector. In each village, 3-4 water sources used for drinking purposes were sampled and analysed. These sources belonged to 5 main categories (Figure 2):

- $\quad$ Category 1: piped water (Figure 2a); 
- Category 2: boreholes with a hand pump (Figure 2b); average depth $30 \mathrm{~m}$;

- Category 3: open hand dug wells with concrete walls (Figure 2c); average depth $16 \mathrm{~m}$;

- Category 4: simple open hand dug wells, that do not have sealed walls (Figure 2d); average depth $5 \mathrm{~m}$;

- Category 5: surface waters (Figure 2e).

In total, 38 water sources were considered for the study: $3(8 \%), 9(24 \%), 10(24 \%), 7(19 \%)$ and $9(24 \%)$ for the categories $1,2,3,4$ and 5 respectively.

Figure 1. (a) Location of the Logone valley in Chad-Cameroon; (b) Location of the target villages in the Logone Valley.

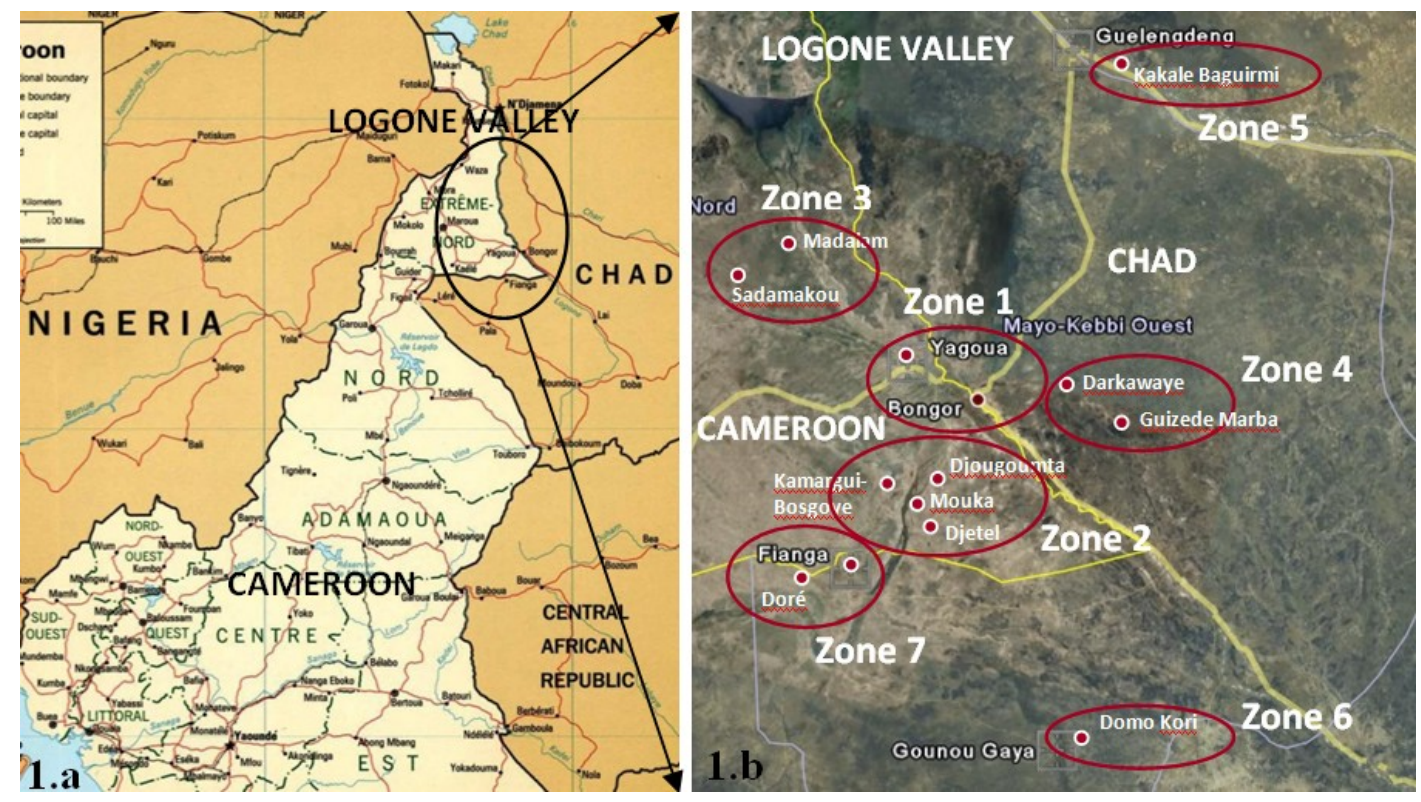

Table 1. Primary water source in the target villages.

\begin{tabular}{c|c}
\hline Village & Source more used \\
\hline Yagoua & Category 1 \\
Djougoumta & Categories 2, 3, 4 and 5 \\
Djetel & Category 2 \\
Mouka & Category 4 \\
Kamargui-Bosgoye & Category 3 \\
Madalam & Category 5 \\
Sadamakou & Category 3 \\
Bongor & Category 1 \\
Darkawaye & Category 4 \\
Guizede Marba & Category 3 \\
Kakale Baguirmi & Category 5 \\
Domo Kori & Category 4 \\
Doré & Category 2 \\
Fianga & All categories \\
\hline
\end{tabular}

Category 1: piped water; Category 2: boreholes with hand pump; Category 3: open dug wells with concrete walls; Category 4: simple open dug wells; Category 5: surface waters. 
Figure 2. Typical sources analysed in the target villages of the study. (a) Piped water (category 1); (b) Boreholes with a hand pump (category 2); (c) Open dug wells with concrete walls (category 3); (d) Simple open dug wells (category 4); (e) Surface waters (category 5).

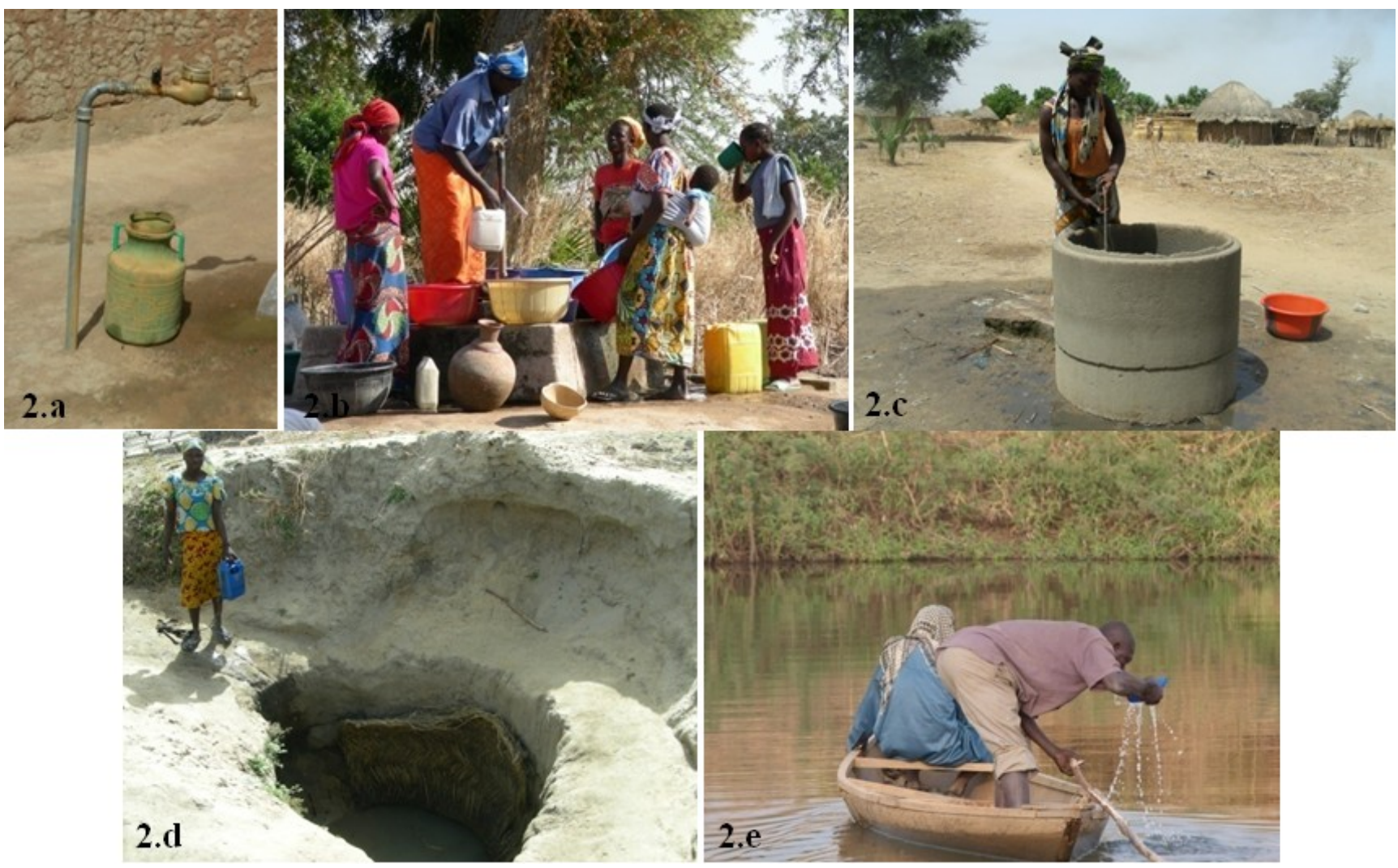

\subsection{Physical-Chemical Analyses}

Water samples were collected from the different sources applying the procedures indicated by Bartram and Balance [18] and WHO [19]. The main physical-chemical parameters were measured directly in the field by the WTW Photoflex Turb Set ( $\mathrm{pH}$ and turbidity) and by the Conductivity Meter AL20 CON (conductivity and temperature), while the others were analysed in the laboratory (see Table 3). All the sampling containers were washed with distilled water and then washed again with the target water before sampling. The samples for metallic element determinations (iron, manganese, zinc, copper, lead, cadmium and chromium) were stored in $0.5 \mathrm{~L}$ polyethylene bottles, where concentrated nitric acid was dosed to reach a $\mathrm{pH}<2$. Also the samples for nitrate and phosphate determinations were stored in $0.5 \mathrm{~L}$ polyethylene bottles, where concentrated sulphuric acid was dosed to reach a $\mathrm{pH}<2$. Finally, the samples for the other determinations (hardness, chloride, fluoride) were collected separately in $0.5 \mathrm{~L}$ plastic bottles. The samples were then immediately stored in ice boxes and once in the laboratory were filtered onto a $0.2 \mu \mathrm{m}$ membrane (except for the samples from taps and boreholes) and analysed. The photometer WTW Photoflex Turb Set was used to measure hardness, chloride, nitrate, phosphate, sulphate, iron, manganese, zinc, copper, lead, cadmium and chromium (VI). Fluoride was measured by the Ionometer WTW pH/ION 340i. Table 2 summarizes the water quality parameters, the analytical methods and the instruments used for the analyses. 
Table 2. Water quality parameters and analytical methods for water source evaluation.

\begin{tabular}{|c|c|c|}
\hline Parameter & Analytical method & Instrument \\
\hline $\mathrm{pH}$ & Instrumental, analyse on site & $\begin{array}{c}\text { Multi-parameter WTW, model Photoflex Turb Set } \\
\text { and probe Sentix } 41\end{array}$ \\
\hline Temperature & Instrumental, analyse on site & Conductivity Meter Aqualitic, model AL20 CON \\
\hline Conductivity & Instrumental, analyse on site & Conductivity Meter Aqualitic, model AL20 CON \\
\hline Turbidity & Nephelometric method, analyse on site & Multi-parameter WTW, model Photoflex Turb Set \\
\hline $\begin{array}{l}\text { Hardness } \\
\text { Chloride }\end{array}$ & Photometric method & Photometer WTW, model Photoflex Turb Set \\
\hline Fluoride & Potentiometric method & $\begin{array}{l}\text { Ionometer WTW, model } \mathrm{pH} / \mathrm{ION} 340 \mathrm{i} \text { and probe F- } \\
\qquad 800\end{array}$ \\
\hline Sulphate & \multirow{10}{*}{ Photometric method } & \multirow{10}{*}{ Photometer WTW, model Photoflex Turb Set } \\
\hline Nitrate & & \\
\hline Phosphate & & \\
\hline Iron & & \\
\hline Manganese & & \\
\hline Zinc & & \\
\hline Copper & & \\
\hline Lead & & \\
\hline Cadmium & & \\
\hline Chrome (VI) & & \\
\hline
\end{tabular}

\subsection{Data Processing and Statistical Analyses}

The quality of drinking water and the water pollution status were evaluated according to the standards suggested by WHO [8] in order to calculate the number of samples that did not comply with the guideline values.

Basic statistical parameters such as minimum, maximum, mean, median and deviation standard were used to analyse the data and to evaluate the dispersion of the values for each parameter and for each source category. Then, the correlation between samples was determined by principal component analysis (PCA) using stat box 6.6 software (Stat Box logiciels, Grimmersoft, France). In this way, statistical evidence was used to provide additional information on analysed water sample results.

\section{Results}

\subsection{Physical-Chemical Analyses}

The results of physical-chemical analysis (mean \pm standard deviation, minimum, median, maximum values) are indicated in Tables 3 and 4 . The value of these statistical parameters is first presented considering all the sampling points and then stratifying the data by the source categories. The number of samples analysed (N), the applicable WHO GVs [8] for drinking water and the percentage of samples with concentrations not within the GVs are also indicated. Chloride, sulphate, copper, cadmium and chromium (VI) are not included in the Tables since their concentrations were always below the detection limit of the analytical instruments (and also of WHO GVs). 
Table 3. Distribution of the main physical-chemical parameters in the samples.

\begin{tabular}{|c|c|c|c|c|c|c|c|c|}
\hline Parameter & Source category & $\mathrm{N}$ & Mean \pm St.Dev & Min & Median & Max & WHO GV & $\begin{array}{c}\% \text { not within } \\
\text { GV }\end{array}$ \\
\hline \multirow{6}{*}{$\mathrm{pH}$} & All & 38 & $6.7 \pm 0.5$ & 5.9 & 6.7 & 7.9 & $6.5-8.5$ & 26 \\
\hline & 1 & 3 & $7.1 \pm 0.2$ & 6.8 & 7.1 & 7.4 & \multirow{5}{*}{$6.5-8.5$} & 0 \\
\hline & 2 & 9 & $6.6 \pm 0.2$ & 6.4 & 6.6 & 7.0 & & 22 \\
\hline & 3 & 10 & $6.6 \pm 0.3$ & 6.1 & 6.6 & 7.0 & & 30 \\
\hline & 4 & 7 & $6.4 \pm 0.4$ & 5.9 & 6.5 & 7.1 & & 71 \\
\hline & 5 & 9 & $7.3 \pm 0.4$ & 6.6 & 7.3 & 7.9 & & 0 \\
\hline \multirow{6}{*}{$\begin{array}{l}\text { Conductivity } \\
(\mu \mathrm{S} / \mathrm{cm})\end{array}$} & All & 38 & $243 \pm 195$ & 30 & 220 & 1,128 & - & - \\
\hline & 1 & 3 & $198 \pm 73$ & 95 & 249 & 250 & \multirow{5}{*}{-} & - \\
\hline & 2 & 9 & $250 \pm 88$ & 54 & 300 & 350 & & - \\
\hline & 3 & 10 & $370 \pm 266$ & 159 & 294 & 1,128 & & - \\
\hline & 4 & 7 & $239 \pm 209$ & 30 & 186 & 687 & & - \\
\hline & 5 & 9 & $111 \pm 52$ & 56 & 85 & 218 & & - \\
\hline \multirow{6}{*}{$\begin{array}{c}\text { Temperature } \\
\left({ }^{\circ} \mathrm{C}\right)\end{array}$} & All & 38 & $29.0 \pm 2.3$ & 24.2 & 29.8 & 33.7 & - & - \\
\hline & 1 & 3 & $32.6 \pm 0.8$ & 32.0 & 32.2 & 33.7 & \multirow{5}{*}{-} & - \\
\hline & 2 & 9 & $29.7 \pm 1.3$ & 27.5 & 30.3 & 31.0 & & - \\
\hline & 3 & 10 & $29.7 \pm 1.8$ & 26.7 & 30.3 & 31.9 & & - \\
\hline & 4 & 7 & $27.5 \pm 2.1$ & 24.2 & 27.1 & 30.1 & & - \\
\hline & 5 & 9 & $27.3 \pm 2.2$ & 24.3 & 27.3 & 30.4 & & - \\
\hline \multirow{6}{*}{$\begin{array}{l}\text { Turbidity } \\
\text { (NTU) }\end{array}$} & All & 38 & $62.7 \pm 119.9$ & 0.2 & 14.2 & 544.0 & 5.0 & 66 \\
\hline & 1 & 3 & $81.8 \pm 111.9$ & 0.5 & 4.7 & 240.0 & \multirow{5}{*}{5.0} & 33 \\
\hline & 2 & 9 & $2.6 \pm 2.8$ & 0.2 & 1.5 & 9.5 & & 22 \\
\hline & 3 & 10 & $15.0 \pm 15.8$ & 1.7 & 6.8 & 53.3 & & 60 \\
\hline & 4 & 7 & $123.4 \pm 148.5$ & 14.3 & 46.9 & 395.0 & & 100 \\
\hline & 5 & 9 & $122.2 \pm 162.6$ & 13.4 & 46.3 & 544.0 & & 100 \\
\hline \multirow{6}{*}{$\begin{array}{c}\text { Hardness } \\
\left({ }^{\circ} \mathrm{f}\right)\end{array}$} & All & 18 & $7.6 \pm 8.4$ & 0.3 & 5.5 & 39.8 & - & - \\
\hline & 1 & 2 & $4.75 \pm 1.0$ & 3.8 & 4.8 & 5.8 & \multirow{5}{*}{-} & - \\
\hline & 2 & 6 & $7.25 \pm 3.2$ & 3.5 & 6.3 & 13.3 & & - \\
\hline & 3 & 5 & $13.6 \pm 13.2$ & 4.0 & 9.0 & 39.8 & & - \\
\hline & 4 & 2 & $2.5 \pm 1.8$ & 0.8 & 2.5 & 4.3 & & - \\
\hline & 5 & 3 & $3.6 \pm 3.7$ & 0.3 & 1.8 & 8.8 & & - \\
\hline
\end{tabular}

Category 1: piped water; Category 2: boreholes with a hand pump; Category 3: open dug wells with concrete walls; Category 4: simple open dug wells; Category 5: surface waters. World Health Organisation (WHO) Guide Value $(\mathrm{GV})$.

The majority of the sources had a $\mathrm{pH}$ lower than the neutrality. Low $\mathrm{pH}$ values were typical of boreholes and open dug wells, while piped and surface waters were near to neutrality. There is no health based guideline for $\mathrm{pH}$, although a range of 6.5-8.5 is suggested by WHO. Of the samples $26 \%$ fell outside the recommended $\mathrm{pH}$ range, being acidic in nature. Literature data [20-23] demonstrated that, at low $\mathrm{pH}$, water can be corrosive and cause damage to equipment, since it can increase metal leaching from pipes and fixtures, such as copper and lead. As a consequence, low $\mathrm{pH}$ values indirectly affect human health, since heavy metals released into the water from pipes can have adverse 
consequences on people. Damaged metal pipes due to acidic $\mathrm{pH}$ values can also lead to aesthetic problems, causing water to have a metallic or sour taste. The minimum and maximum $\mathrm{pH}$ values (5.9 and 7.9) were observed respectively in the simple open dug wells of Domo Kori (Chad) and in the surface water (Logone River) sampled near Bongor city (Chad).

Table 4. Distribution of other chemical parameters in the samples.

\begin{tabular}{|c|c|c|c|c|c|c|c|c|}
\hline Parameter & $\begin{array}{c}\text { Source } \\
\text { category }\end{array}$ & $\mathbf{N}$ & Mean \pm St.Dev & Min & Median & $\operatorname{Max}$ & $\begin{array}{c}\text { WHO } \\
\text { GV }\end{array}$ & $\begin{array}{c}\% \text { not within } \\
\text { GV }\end{array}$ \\
\hline \multirow{6}{*}{$\begin{array}{l}\text { Fluoride } \\
(\mathrm{mg} / \mathrm{L})\end{array}$} & All & 38 & $0.17 \pm 0.22$ & 0.05 & 0.10 & 1.10 & 1.50 & 0 \\
\hline & 1 & 3 & $0.2 \pm 0.12$ & 0.11 & 0.21 & 0.40 & \multirow{5}{*}{1.50} & 0 \\
\hline & 2 & 9 & $0.16 \pm 0.12$ & 0.07 & 0.10 & 0.41 & & 0 \\
\hline & 3 & 10 & $0.15 \pm 0.09$ & 0.05 & 0.11 & 0.36 & & 0 \\
\hline & 4 & 7 & $0.21 \pm 0.36$ & 0.05 & 0.06 & 1.10 & & 0 \\
\hline & 5 & 9 & $0.22 \pm 0.27$ & 0.09 & 0.13 & 0.97 & & 0 \\
\hline \multirow{6}{*}{$\begin{array}{l}\text { Nitrate } \\
\left(\mathrm{mg} / \mathrm{L} \mathrm{NO}_{3}-\mathrm{N}\right)\end{array}$} & All & 36 & $1.5 \pm 4.7$ & 0.0 & 0.3 & 27.6 & 50.0 & 0 \\
\hline & 1 & 3 & $0.7 \pm 0.6$ & 0.2 & 0.4 & 1.5 & \multirow{5}{*}{50.0} & 0 \\
\hline & 2 & 7 & $0.3 \pm 0.4$ & 0.0 & 0.1 & 1.2 & & 0 \\
\hline & 3 & 10 & $3.4 \pm 8.1$ & 0.0 & 0.4 & 27.6 & & 0 \\
\hline & 4 & 7 & $2.0 \pm 2.8$ & 0.2 & 1.3 & 8.8 & & 0 \\
\hline & 5 & 9 & $0.4 \pm 0.5$ & 0.0 & 0.2 & 1.8 & & 0 \\
\hline \multirow{6}{*}{$\begin{array}{l}\text { Phosphate } \\
\left(\mathrm{mg} / \mathrm{L} \mathrm{PO}_{4}-\mathrm{P}\right)\end{array}$} & All & 36 & $0.37 \pm 0.38$ & 0.00 & 0.25 & 1.86 & - & - \\
\hline & 1 & 3 & $0.66 \pm 0.33$ & 0.30 & 0.58 & 1.10 & \multirow{5}{*}{ - } & - \\
\hline & 2 & 7 & $0.41 \pm 0.32$ & 0.04 & 0.29 & 1.06 & & - \\
\hline & 3 & 10 & $0.38 \pm 0.24$ & 0.09 & 0.30 & 0.77 & & - \\
\hline & 4 & 7 & $0.47 \pm 0.60$ & 0.01 & 0.25 & 1.86 & & - \\
\hline & 5 & 9 & $0.14 \pm 0.14$ & 0.00 & 0.07 & 0.48 & & - \\
\hline \multirow{6}{*}{$\begin{array}{l}\text { Iron } \\
(\mathrm{mg} / \mathrm{L})\end{array}$} & All & 38 & $3.71 \pm 6.93$ & 0.00 & 0.39 & 25.20 & 0.30 & 55 \\
\hline & 1 & 3 & $6.54 \pm 9.24$ & 0.00 & 0.01 & 19.60 & \multirow{5}{*}{0.30} & 33 \\
\hline & 2 & 9 & $6.54 \pm 9.96$ & 0.00 & 0.94 & 25.20 & & 67 \\
\hline & 3 & 10 & $1.97 \pm 4.40$ & 0.05 & 0.26 & 15.00 & & 40 \\
\hline & 4 & 7 & $4.35 \pm 6.25$ & 0.04 & 0.26 & 16.30 & & 43 \\
\hline & 5 & 9 & $1.37 \pm 1.79$ & 0.20 & 0.70 & 6.20 & & 78 \\
\hline \multirow{6}{*}{$\begin{array}{l}\text { Manganese } \\
(\mathrm{mg} / \mathrm{L})\end{array}$} & All & 38 & $0.27 \pm 0.42$ & 0.00 & 0.00 & 1.50 & 0.40 & 24 \\
\hline & 1 & 3 & $0.3 \pm 0.42$ & 0.00 & 0.00 & 0.90 & \multirow{5}{*}{0.40} & 33 \\
\hline & 2 & 9 & $0.36 \pm 0.52$ & 0.00 & 0.00 & 1.50 & & 33 \\
\hline & 3 & 10 & $0.24 \pm 0.39$ & 0.00 & 0.00 & 1.10 & & 20 \\
\hline & 4 & 7 & $0.37 \pm 0.41$ & 0.00 & 0.20 & 1.10 & & 29 \\
\hline & 5 & 9 & $0.12 \pm 0.28$ & 0.00 & 0.00 & 0.90 & & 11 \\
\hline \multirow{6}{*}{$\begin{array}{l}\text { Zinc } \\
(\mathrm{mg} / \mathrm{L})\end{array}$} & All & 20 & $0.14 \pm 0.14$ & 0.02 & 0.07 & 0.56 & 3.00 & 0 \\
\hline & 1 & 3 & $0.23 \pm 0.07$ & 0.17 & 0.18 & 0.32 & \multirow{5}{*}{3.00} & 0 \\
\hline & 2 & 5 & $0.23 \pm 0.20$ & 0.03 & 0.15 & 0.56 & & 0 \\
\hline & 3 & 4 & $0.08 \pm 0.05$ & 0.04 & 0.07 & 0.16 & & 0 \\
\hline & 4 & 3 & $0.13 \pm 0.08$ & 0.04 & 0.13 & 0.22 & & 0 \\
\hline & 5 & 5 & $0.03 \pm 0.01$ & 0.02 & 0.03 & 0.04 & & 0 \\
\hline
\end{tabular}


Table 4. Cont.

\begin{tabular}{|c|c|c|c|c|c|c|c|c|}
\hline Parameter & $\begin{array}{c}\text { Source } \\
\text { category }\end{array}$ & $\mathbf{N}$ & Mean \pm St.Dev & Min & Median & Max & $\begin{array}{c}\text { WHO } \\
\text { GV }\end{array}$ & $\begin{array}{c}\text { \% not within } \\
\text { GV }\end{array}$ \\
\hline \multirow{6}{*}{$\begin{array}{l}\text { Lead } \\
(\mathrm{mg} / \mathrm{L})\end{array}$} & All & 37 & $0.29 \pm 0.39$ & 0.01 & 0.12 & 1.52 & 0.01 & 95 \\
\hline & 1 & 3 & $0.15 \pm 0.15$ & 0.02 & 0.07 & 0.36 & \multirow{5}{*}{0.01} & 100 \\
\hline & 2 & 9 & $0.52 \pm 0.56$ & 0.02 & 0.21 & 1.52 & & 100 \\
\hline & 3 & 10 & $0.32 \pm 0.36$ & 0.02 & 0.14 & 1.13 & & 100 \\
\hline & 4 & 7 & $0.23 \pm 0.19$ & 0.02 & 0.18 & 0.63 & & 100 \\
\hline & 5 & 8 & $0.06 \pm 0.05$ & 0.01 & 0.03 & 0.14 & & 75 \\
\hline
\end{tabular}

Category 1: piped water; Category 2: boreholes with a hand pump; Category 3: open dug wells with concrete walls; Category 4: simple open dug wells; Category 5: surface waters.

Turbidity should ideally be below 5 NTU, since the appearance of water with a turbidity of less than this value is usually acceptable to consumers [8]. It does not have a health based guideline; nevertheless, microorganisms (bacteria, viruses and protozoa) are typically attached to particulates [8]. As a consequence, turbid waters can be microbiologically contaminated and indirectly constitute a health issue. Furthermore, high levels of turbidity can protect microorganisms from the effects of disinfection, giving rise to a significant chlorine demand and reducing the performance of some disinfection treatments, like SODIS [8]. Thus, turbidity could represent a key issue regarding the microbiological quality and disinfection of water. Of the samples in the Logone valley $66 \%$ were above this guideline and the turbidity was generally a problem in the simple open dug wells and in surface waters. The highest values were observed in the simple open dug wells of Kamargui-Borgoye (315 NTU) and Madalam (395 NTU) in Cameroon, with a peak (544 NTU) measured in the surface water (lake) sampled in Fianga city (Chad). High values were also found in the piped water of Fianga (244 NTU) and in the open dug well with concrete walls of Djougoumta (53 NTU). The minimum turbidity (0.2 NTU) was measured in the borehole of Guizede Marba (Chad).

The waters of the Logone valley are also rich in iron, especially in the villages of Djougoumta, Mouka, Djetel, Kamargui-Bosgoye (Cameroon) and Fianga (Chad). The highest values were measured in the borehole $(25.2 \mathrm{mg} / \mathrm{L})$ and in the open dug well with concrete walls $(15.0 \mathrm{mg} / \mathrm{L})$ in Djougoumta and in the piped water in Fianga $(19.6 \mathrm{mg} / \mathrm{L})$. No health-based guideline value is proposed for iron, although taste (organoleptic problem) is affected above $300 \mu \mathrm{g} / \mathrm{L}$ [8]. Of the samples in the Logone valley 55\% were above this value. This percentage and the high concentrations measured in some sources attest that the taste of water (and also the colour) is a concern in this area. In fact, results from the initial survey (questionnaires) showed that surface waters with lower concentrations were preferred for drinking use and washing clothes, rather than highly iron-concentrated sources.

The presence of iron in the waters of the Logone valley is first of all associated with the territory. In fact the villages affected by this problem belong to the same area (Zone 2 in Cameroon and Zone 7 in Chad), that overlooks lake Guere. On the contrary, sources in the other villages did not show problems of iron and a total absence was observed in the piped water of Yagoua (Cameroon) and in the borehole of Doré (Chad). Secondly, iron concentration depends on the sampled water table. In fact, considering boreholes and shallow open wells, it was observed that Fe concentrations increased with the depth of the water. As an example, in Fianga, piped water that showed problems of iron comes from a $30 \mathrm{~m}$ deep water table, while other source categories that catch the superficial water table $(<10 \mathrm{~m} \mathrm{deep})$ had 
iron concentrations not exceeding the WHO organoleptic standard $(0.3 \mathrm{mg} / \mathrm{L})$. Surface waters were also found to be contaminated by iron, since $78 \%$ of the samples did not comply with the WHO GV, even though their concentrations were lower than concentrations found in other source categories.

Therefore, the immediate environment of these sources was reducing in nature since the chemistry of naturally occurring Fe is controlled by the redox conditions of the water and Fe is mobilised under reducing conditions [5]. The input of iron in superficial waters is due to the phenomenon of soil leaching and the input in underground waters is the result of the water-rock interaction.

Concerning manganese, $24 \%$ of the sampled sources had concentrations exceeding the WHO GV of $0.4 \mathrm{mg} / \mathrm{L}$. The maximum value $(1.5 \mathrm{mg} / \mathrm{L})$ was observed in the borehole of Kamargui-Bosgoye (Cameroon). Furthermore, Fe and Mn showed a similar behaviour. In fact, high concentrations of Mn were found in the same sources where Fe was high. Secondly, Mn concentrations increased with water depth, as observed for iron. Manganese is an essential human micronutrient and most human intake occurs through consumption of various types of food. Inhalation studies linked chronic manganese intake with neurological disorders; however, data on the human health effects of long-term exposure to elevated manganese levels through oral intake (food and water) are still limited [8,24]. The first epidemiological studies associated adverse neurological effects with long-term exposure to manganese from drinking water [25-27]. However, in a recently published study [28], a child exposed to increased manganese in drinking water and affected by increased manganese levels in his hair and blood did not exhibit any evident clinical effects of manganese over-exposure, except for difficulties in both visual and verbal memory. No studies are available on the potential carcinogenicity of exposure to high levels of manganese in humans [24]. Due to a lack of qualitative and quantitative details of the exposure scenario, these and other similar studies cannot be used for quantitative assessment [29] and manganese is primarily referred to in regulations $[8,30]$ as a parameter regarding public acceptance of drinking water rather than human health.

WHO [8] sets a health based guideline of $0.01 \mathrm{mg} / \mathrm{L}$ for lead concentration in drinking water, as it is a general toxicant that accumulates in the skeleton and that causes adverse neurological effects after long-term exposure. During the monitoring in the Logone valley, lead concentration did not comply with the WHO GV $(0.01 \mathrm{mg} / \mathrm{L})$ in $95 \%$ of the sources. In particular, it exceeded this standard in $100 \%$ of the piped waters, boreholes and open dug wells, while $25 \%$ of the sampled superficial waters had a lead concentration below $0.01 \mathrm{mg} / \mathrm{L}$. A maximum value of $1.5 \mathrm{mg} / \mathrm{L}$ was measured in the borehole of Kamargui-Bosgoye, while a minimum value of $0.01 \mathrm{mg} / \mathrm{L}$ was measured in the Logone river near Yagoua. In the same way as for $\mathrm{Fe}$ and $\mathrm{Mn}$, high concentrations of $\mathrm{Pb}$ were also found mostly in boreholes rather than in shallow open wells and in surface waters, so that a correlation with the depth of the water could be possible. Furthermore, high concentrations were measured mainly in zones 2 and 7, as observed for iron and manganese.

Most lead in drinking-water arises from plumbing. So, it is possible that boreholes and open dug wells with concrete walls were constructed with materials containing this metal. Nevertheless, lead was found also in superficial waters and in simple open dug wells with ground walls; as a consequence its presence in these source typologies has a different origin. The Logone valley is a rural area with no industrial activities or uncontrolled dumping and therefore such high concentrations of lead could not be possible from such sources. As a consequence, lead in such waters could originate from sources other than human pollution and it could be due to the geology of the subsoil $[16,17]$. 
Regarding the chemical parameters of main concern (turbidity, iron, manganese and lead), Table 5 reports the villages at higher risk, specifying the level of contamination of the water sources.

Furthermore, Figure 3 shows that the water sources in zones 2 (Cameroon) and 7 (Chad) are the most contaminated. In addition, in Figure 4 it is possible to observe that the deep waters (tap waters and boreholes with a hand pump) have the highest concentrations, followed by waters from shallow wells (open wells with concrete walls and simple open wells) and by surface waters.

Table 5. Villages with the highest concentrations of turbidity, iron, manganese and lead.

\begin{tabular}{c|c|c|c|c|c}
\hline \multirow{2}{*}{ Village } & $\begin{array}{c}\text { Source } \\
\text { category }\end{array}$ & $\begin{array}{c}\text { Turbidit } \\
\mathbf{y}(\mathbf{N T U})\end{array}$ & $\begin{array}{c}\mathbf{F e} \\
(\mathbf{m g} / \mathbf{L})\end{array}$ & $\begin{array}{c}\mathbf{M n} \\
(\mathbf{m g} / \mathbf{L})\end{array}$ & $\begin{array}{c}\mathbf{P b} \\
(\mathbf{m g} / \mathbf{L})\end{array}$ \\
\hline \multirow{2}{*}{$\begin{array}{c}\text { Kamargui- } \\
\text { Bosgoye }\end{array}$} & 2 & 9.5 & 5.7 & 1.5 & 1.5 \\
\cline { 2 - 6 } & 4 & 315.0 & 11.7 & 0.9 & 0.6 \\
\hline \multirow{2}{*}{ Djougoumta } & 2 & 2.9 & 25.2 & 0.7 & 1.3 \\
\cline { 2 - 6 } & 3 & 53.3 & 15.0 & 1.1 & 1.1 \\
\hline Djetel & 3 & 29.3 & 2.5 & 0.9 & 0.8 \\
\hline Mouka & 4 & 23.0 & 16.3 & 0.3 & 0.3 \\
\hline \multirow{2}{*}{ Fianga } & 1 & 240.0 & 19.6 & 0.9 & 0.4 \\
\cline { 2 - 6 } & 2 & 5.1 & 24.6 & 0.9 & 1.0 \\
\hline \multirow{2}{*}{ Madalam } & 4 & 394.0 & 0.3 & 0.2 & 0.3 \\
\hline
\end{tabular}

Category 1: piped water; Category 2: boreholes with a hand pump; Category 3: open dug wells with concrete walls; Category 4: simple open dug wells; Category 5: surface waters.

Figure 3. Iron, manganese and lead mean concentrations stratified by the territorial zones in the Logone valley.

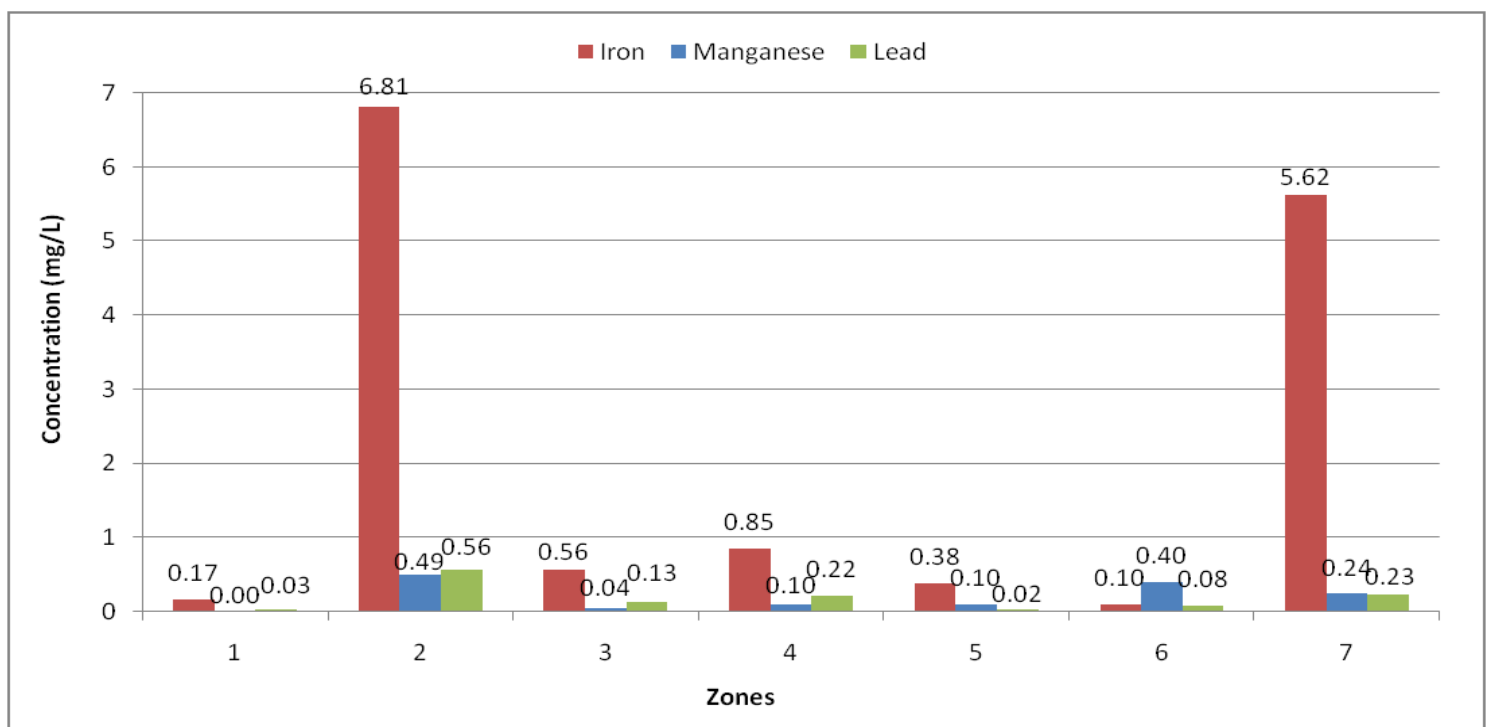

Zone 1: Number of samples $\mathrm{N}=4$; Zone 2: $\mathrm{N}=13$; Zone $3: \mathrm{N}=5$; Zone 4: $\mathrm{N}=4$; Zone 5: $\mathrm{N}=1$; Zone 6: $\mathrm{N}=3$; Zone $7: \mathrm{N}=8$. 
Figure 4. Iron, manganese and lead mean concentrations stratified by the depth of water sources.

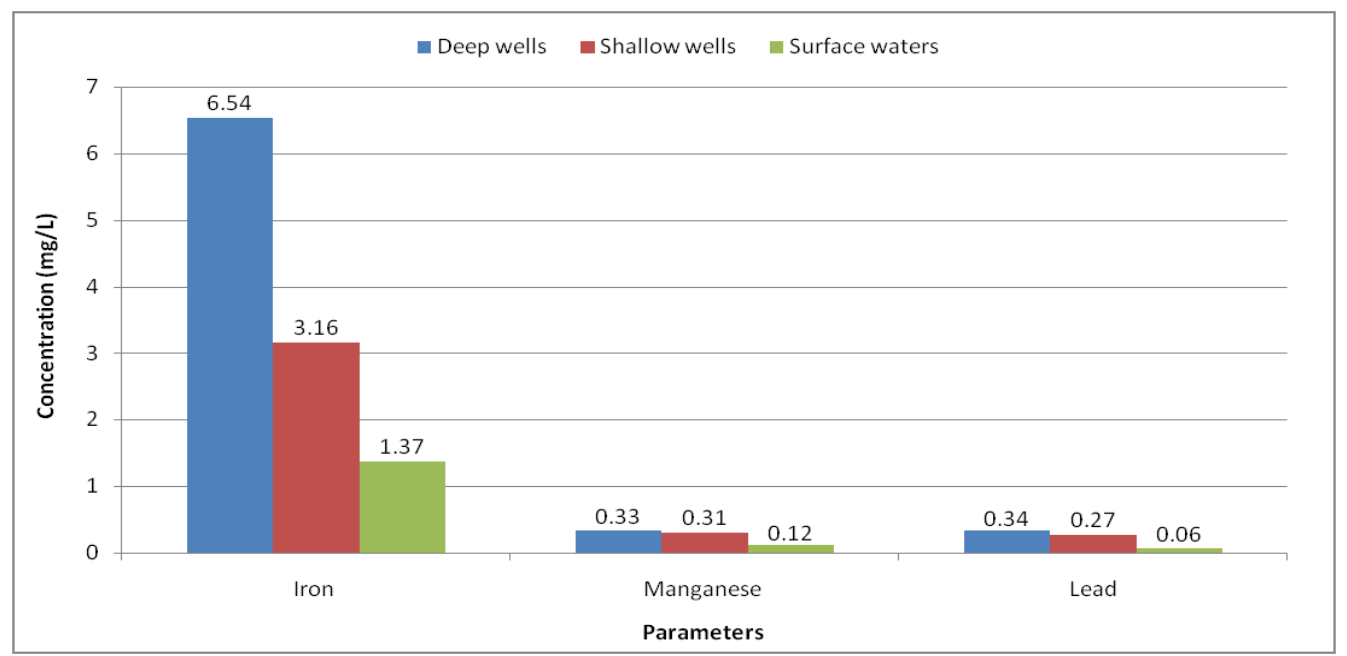

Deep wells: Number of samples $\mathrm{N}=12$; Shallow wells: $\mathrm{N}=17$; Surface waters: $\mathrm{N}=9$.

\subsection{PCA Profiles of Correlation between Different Parameters}

The correlation between parameters was profiled using Principal Component Analysis (PCA). Figure 5a shows the correlation circle where all water quality parameters are represented. Figure $5 \mathrm{~b}$ represents the results of the PCA performed on the different categories of water samples (individuals) from Cameroon and Chad, with respect to the first (PC1) and the second (PC2) principal components (axes). The first and the second principal components respectively explained $28 \%$ and $24 \%$ of the total inertia, corresponding to a total of $52 \%$. Table 6 shows the value of the correlation between variables and axes as shown by PCA.

Based on the PCA analysis, variables like turbidity, temperature, fluoride and $\mathrm{pH}$ were not significant and had less influence on the statistical analysis. In decreasing order, $\mathrm{Fe}, \mathrm{Pb}, \mathrm{Zn}$ and $\mathrm{Mn}$ were highly and positively correlated to $\mathrm{PC} 1$ whereas $\mathrm{pH}$ and fluoride were negatively correlated. Compared with axis PC2, in decreasing order, nitrate, conductivity, hardness, temperature and fluoride were positively correlated whereas phosphate, lead, iron, turbidity and manganese were negatively correlated. The Pearson analysis at the probability of 0.05 showed that conductivity and nitrate, conductivity and hardness, temperature and conductivity, hardness and nitrate, phosphate and iron, phosphate and zinc, iron and manganese, iron and zinc, iron and lead, zinc and lead were significantly correlated. Based on the PCA analysis, three profiles could be identified: profile 1 consisted in variables (conductivity, temperature, hardness, nitrate and zinc) positively correlated to axis $\mathrm{PC} 1$ and PC2, profile 2 consisted in variables (turbidity, phosphate, iron, manganese and lead) positively correlated to axis $\mathrm{PC} 1$ and negatively correlated to axis $\mathrm{PC} 2$, profile 3 consisted in variables $(\mathrm{pH}$, fluoride) negatively correlated to axis PC1 and positively correlated to axis PC2. The analysis showed that that the mineral composition of the water sample does not depend on the country, since the samples in Cameroon and Chad had the same composition. 
Figure 5. Distribution of the physical-chemical parameters with respect to the first and the second principal components in the sampled boreholes with a hand pump, open dug wells with concrete walls, simple open dug wells and surface waters. (a) Correlation circle; (b) Results of the principal component analysis.

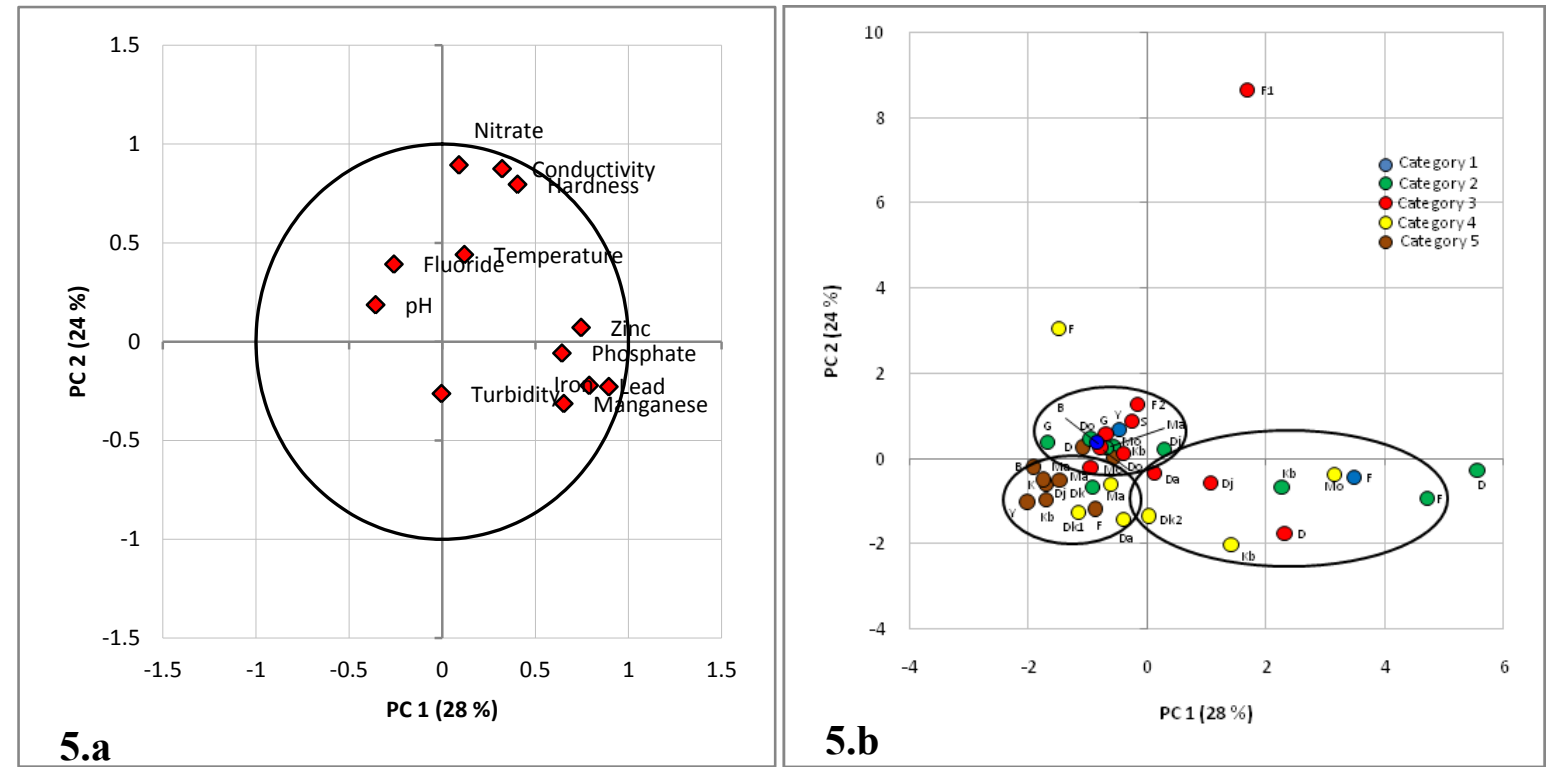

Category 1: piped water; Category 2: boreholes with a hand pump; Category 3: open dug wells with concrete walls; Category 4: simple open dug wells; Category 5: surface waters; D: Djougoumta; Dj: Djetel; Mo: Mouka; Kb: Kamargui-Bosgoye; Ma: Madalam; S: Sadamakou; Y: Yagoua; G: Guizede Marba; Da: Darkawaye; Dk: Domo Kory; K: Kakale Baguirmi; F: Fianga; Do: Doré; B: Bongor.

Table 6. Correlation between variables and axes as shown by Principal Component Analysis (PCA).

\begin{tabular}{c|c|c}
\hline & PC 1 & PC 2 \\
\hline pH & -0.36 & 0.19 \\
\hline Conductivity & 0.32 & 0.88 \\
\hline Temperature & 0.12 & 0.44 \\
\hline Turbidity & 0.00 & -0.26 \\
\hline Hardness & 0.40 & 0.80 \\
\hline Fluoride & -0.26 & 0.39 \\
\hline Nitrate & 0.09 & 0.89 \\
\hline Phosphate & 0.64 & -0.06 \\
\hline Iron & 0.89 & -0.23 \\
\hline Manganese & 0.65 & -0.31 \\
\hline Zinc & 0.75 & 0.07 \\
\hline Lead & 0.79 & -0.22 \\
\hline & &
\end{tabular}

\section{Conclusions}

This paper describes a survey carried out in the Logone Valley (Chad-Cameroon) to assess the physical-chemical quality of different types of water sources used by village people for human consumption. As a consequence, this research provided baseline water quality data in this region. 
Furthermore, it contributed to identify the main concerns regarding the quality of drinking water, in order to suggest appropriate solutions to reduce the observed contaminations and to motivate the local public authorities to plan future interventions in this sector.

As regards physical-chemical parameters, the result was that drinking water sources have a reasonably good chemical quality, with key exceptions related to the occurrence of lead contamination. This identified chemical water quality concern is significant and an immediate intervention is required to prevent widespread and long-term exposure. To plan correct actions in the Logone valley it is necessary to clarify the origin of this element in the different source categories. For the supplies where lead arises from plumbing, the remedy consists principally in removing plumbing and fittings containing lead. In the other cases, alternative sources have to be researched or, if not possible, contaminated sources have to be treated before water consumption.

Also the aesthetic properties (iron and manganese) of water supplies are an issue in the Logone valley and should be taken into consideration before developing an intervention program, since consumer acceptance can play a critical role in the long-term sustainability of water supply projects. In fact, most of the interviewed people abandon improved water supplies rich in iron and manganese in favour of surface water sources that are unsafe and microbiologically contaminated. To prevent this behaviour it is possible to persuade people to aerate and settle the collected water for up to one-two days before drinking it in order to improve the water's taste. Though moderately effective, this household treatment approach can increase bacterial contamination if not done in hygienic conditions, since microorganisms in unclean, unlimited-access vessels can proliferate in the water during the settlement time. As an alternative treatment, simple iron reduction filters can be attached to boreholes. If properly maintained, such filters can significantly reduce iron (and manganese) concentrations and improve taste, although ensuring that regular cleaning, replacement of filter media and sterilization processes are undertaken can prove problematic on a community scale.

Finally, further research in water quality would be very beneficial in the development of a future water resource program in the Logone valley. In fact, the origin of iron, manganese and lead needs to be investigated by also considering the hydro-geological characteristics of the sampling sites. Only by identifying the sources of contamination will it be possible to select and implement the most correct and appropriate solution to these quality issues.

\section{Acknowledgments}

The Authors would like to extend their acknowledgements to Alessandro Reitano, Kengne Raissa, Woumbondi Sylvestre, Souloukna Ifassou Jean Marie and Ditcho Azina Sanga for their collaboration in carrying out the analyses in the field, as well as to ACRA and the European Community for providing the financial support.

This paper was undertaken in the framework of the ACP (Africa, Caribbean and Pacific) Science and Technology Programme, a programme of the ACP Group of States, with the financial assistance of the European Union. "The contents of this publication are the sole responsibility of CETAMB (Research Centre on Appropriate Technologies for Environment Management in Developing Countries) and ACRA and can under no circumstances be regarded as reflecting the position of the ACP Secretariat and of the European Union.” This work was developed during the cooperation project 
"Applied research for the exploitation and processing of natural resources within a pathway of poverty reduction in Chad and Cameroon" in the Logone River Valley (Chad-Cameroon) involving the following partners: PRASAC (Regional pole of applied research for the development of agricultural systems in Central Africa) of N'Djamena, University of N'Djamena, University of Ngaundéré, University of Brescia (CeTAmb), University of Milan.

S. Sorlini planned and supervised the experimental research, the data analysis, the paper draft and revision. D. Palazzini executed the monitoring in Chad-Cameroon, analysed and processed the data, contributed to the paper writing and revision. M.B. Ngassoum and J. Sieliechi contributed in the redaction of the statistical analyses and in the hydrogeological study.

\section{Conflict of Interest}

The authors declare no conflict of interest.

\section{References and Notes}

1. WHO; UNICEF. Progress on Sanitation and Drinking Water: 2012 Update; World Health Organisation/UNICEF: Geneva, Switzerland, 2012.

2. WHO; UNICEF. JPM Technical Task Force Meeting on Monitoring Drinking-water Quality. Available online: http://www.wssinfo.org/fileadmin/user_upload/resources/JMP-Task-ForceMeeting-on-Monitoring-Drinking-water-Quality.pdf (accessed on 9 July 2013).

3. Feldman, P.; Rosenboom, J.; Saray, M.; Samnang, C.; Navuth, P.; Iddings, S. Assessment of the chemical quality of drinking water in Cambodia. J. Water Health 2007, 5, 101-116.

4. Quagraine, E.K.; Adokoh, C.K. Assessment of dry season surface, ground, and treated water quality in the Cape Coast municipality of Ghana. Environ. Monit. Assess. 2010, 160, 521-539.

5. Rossiter, H.; Owusu, P.A.; Awuah, E.; MacDonald, A.M.; Schäfer, A.I. Chemical drinking water quality in Ghana: Water costs and scope for advanced treatment. Sci. Total. Environ. 2010, 408, 2378-2386.

6. Rahman, I.M.M.; Islam, M.M.; Hossain, M.M.; Hossain, M.S.; Begum, Z.A.; Chowdhury, D.A.; Chakraborty, M.K.; Rahman, M.A.; Nazimuddin, M.; Hasegawa, H. Stagnant surface water bodies (SSWBs) as an alternative water resource for the Chittagong metropolitan area of Bangladesh: physicochemical characterization in terms of water quality indices. Environ. Monit. Assess. 2011, 173, 669-684.

7. Adekunle, I.M.; Adetunji, M.T.; Gbadebo, A.M.; Banjoko, O.B. Assessment of groundwater quality in a typical rural settlement in Southwest Nigeria. Int. J. Environ. Res. Public. Health. 2007, 4, 307-318.

8. WHO. Guidelines for Drinking-Water Quality, 4th ed.; World Health Organisation: Geneva, Switzerland, 2012.

9. Hoko, Z. An assessment of quality of water from boreholes in Bindura District, Zimbabwe. Phys. Chem. Earth, Parts A/B/C 2008, 33, 824-828.

10. Mbawala, A.; Abdou, A.; Ngassoum, M.B. Evaluation de la pollution physico-chimique et microbienne des eaux de puits de Dang-Ngaoundéré (Cameroun) (in French). IJBCS 2010, 4, 1962-1975. 
11. Memon, M.; Soomro, M.S.; Akhtar, M.S.; Memon, K.S. Drinking water quality assessment in Southern Sindh (Pakistan). Environmen. Monit. Assess. 2011, 177, 39-50.

12. Sharaky, A.M.; Atta, S.A.; El Hassanein, A.S.; Khallaf, K.M.A. Hydrogeochemistry of Groundwater in the Western Nile Delta Aquifers, Egypt. In Proceeding of the 2nd International Conference on the Geology of Tethys, Cairo, Egypt, 19-21 March 2007; pp. 19-21.

13. Cobbina, S.J.; Nyame, F.K.; Obiri, S. Groundwater Quality in the Sahelian Region of Northern Ghana, West Africa. Res. J. Environ. Earth. Sci. 2012, 4, 482-491.

14. Tchounwou, P.B.; Lantum, D.M.; Monkiedje, A.; Takougang, I.; Barbazan, P. The urgent need for environmental sanitation and a safe drinking water supply in Mbandjock, Cameroon. Arch. Environ. Contam. Toxicol. 1997, 33, 17-22.

15. Mkandawire, T. Quality of groundwater from shallow wells of selected villages in Blantyre District, Malawi. Phys. Chem. Earth, Parts A/B/C 2008, 33, 807-811.

16. Ketchemen, B. Etude hydrogéologique du grand Yaéré (Extrême-Nord du Cameroun); synthèse hydrogéologique et étude de la recharge par les isotopes de l'environnement (in French). Ph.D. Thesis, Cheik Anta Diop University, Dakar, Senegal, 1992.

17. Ngatcha, B.N.; Mudry, J.; Aranyossy, J.F.; Naah, E.; Reynault, J.S. Contribution of geology, hydrogeology and environmental isotopes to the knowledge of "piezometric depressions" of the Grand Yaere (Northern Cameroon) (in French). Rev. Sci. Eau 2007, 20, $29-43$.

18. Bartram, J.; Balance, R. Water Quality Monitoring-A Practical Guide to the Design and Implementation of Freshwater Quality Studies and Monitoring Programmes; World Health Organisation: Geneva, Switzerland, 1996.

19. WHO. Guidelines for Drinking-Water Quality, Volume 3, Surveillance and Control of Community Supplies, 2nd ed.; World Health Organisation: Geneva, Switzerland, 1997.

20. Broo, A.E.; Berghult, B.; Hedberg, T. Copper corrosion in drinking water distribution systemsthe influence of water quality. Corrosion Sci. 1997, 39, 1119-1132.

21. Pehkonen, S.O.; Palit, A.; Zhang, X. Effect of specific water quality parameters on copper corrosion. Corrosion 2002, 58, 156-165.

22. Schock, M.R. Causes of temporal variability of lead in domestic plumbing systems. Environ. Monitor. Assess. 1990, 15, 59-82.

23. Kim, E.J.; Herrera, J.E.; Huggins, D.; Braam, J.; Koshowski, S. Effect of $\mathrm{pH}$ on the concentrations of lead and trace contaminants in drinking water: A combined batch, pipe loop and sentinel home study. Water Res. 2011, 45, 2763-2774.

24. ATSDR-Agency for Toxic Substances and Disease Registry. Toxicological Profile for Manganese; US Department of Health and Human Services, Public Health Service: Atlanta, GA, USA, 2000. Available online: www.atsdr.cdc.gov/toxprofiles/tp151.html (accessed on 20 September 2012).

25. Kondakis, X.G.; Makris, N.; Leotsinidis, M.; Prinou, M.; Papapetropoulos, T. Possible health effects of high manganese concentration in drinking water. Arch. Environ. Health 1989, 44, $175-178$.

26. He, P.; Liu, D.H; Zhang, G.Q. Effects of high-level manganese sewage irrigation on children's neurobehavior (in Chinese). Zhonghua Yu Fang Yi Xue Za Zhi 1994, 28, 216-218. 
27. Zhang, G.; Liu, D.; He, P. Effects of manganese on learning abilities in school children (in Chinese). Zhonghua Yu Fang Yi Xue Za Zhi 1995, 29, 156-158.

28. Woolf, A.; Wright, R.; Amarasiriwardena, C.; Bellinger, D. A child with chronic manganese exposure from drinking water. Environ. Health Perspesc. 2002, 110, 613-616.

29. EPA. Drinking Water Health Advisory for Manganese; U.S. Environmental Protection Agency: Washington, DC, USA, 2004.

30. EPA. Secondary drinking water regulations. Available online: http://water.epa.gov/ drink/contaminants/secondarystandards.cfm (accessed on 21 June 2013).

(C) 2013 by the authors; licensee MDPI, Basel, Switzerland. This article is an open access article distributed under the terms and conditions of the Creative Commons Attribution license (http://creativecommons.org/licenses/by/3.0/). 